\title{
APPLICATION OF THE METHOD OF PROBE PARTICLES TO THE AERODYNAMIC CALCULATION OF SPACECRAFT
}

\author{
Institute of Technical Mechanics \\ of the National Academy of Sciences of Ukraine and the State Space Agency of Ukraine \\ 15 Leshko-Popel St., Dnipro 49005, Ukraine; e-mail: office.itm@nas.gov.ua
}

The aim of this paper is to overview the results of the work of the Institute of Technical Mechanics of the National Academy of Sciences of Ukraine and the State Space Agency of Ukraine on further development of the method of probe particles (MPP) and to present the software developed on its basis. The MPP fundamentals are briefly described. The works where the MPP algorithm was tested in one-, two-, and three-dimensional formulation are overviewed. The calculated gas-dynamic parameters (density, velocity, and temperature) in the vicinity of an obstacle, surface distributed heat fluxes, and drag coefficients were compared with their values found analytically, with the results calculated by other methods, and with the calculated and experimental data available in the literature. The testing of the method has shown its workability in different regimes of flow about a body.

The paper shows the spectrum of problems where the MPP is used and the functional capabilities of the software for the calculation of the aerodynamic characteristics of spacecraft and gas-dynamic process in their vicinity developed on its basis. Calculated results are presented for the flow about the third stage of the Cyclone4 launch vehicle with an aerodynamic deorbiting system - a deployed sail braking system in the form of coaxial conical tori. The drag coefficient and the drag area calculated for different angles of attack are compared with their estimated values for a nonoriented spacecraft motion.

Keywords Monte-Carlo method, method of probe particles, numerical simulation, rarefied gas, 3D flow about a body, gas-dynamic parameters, aerodynamic characteristics.

1. Haviland J. K. Solution of two molecular flow problems by the Monte-Carlo method (in Russian). Computational Methods in Rarefied Gas Dynamics. Moscow: Mir, 1969. Pp. 7-115.

2. Haviland J. K., Lavin M. L. Application of the Monte-Carlo method to heat transfer in a rarefied gas. Phys. Fluids. 1962. V. 5. No. 11. Pp. 1399-1405.

3. Grigor'ev Yu. N., Ivanov M. S., Kharitonova N. M. Numerical methods of continuum mechanics (in Russian). VTs SO AN SSSR. V. 2. No. 4. Pp. 101-107.

4. Vlasov V. I. Conservative version of the probe molecule (Monte-Carlo) method (in Russian). Proceedings of the $8^{\text {th }}$ All-Union Conference on Rarefied Gas Dynamics (Numerical and Analytical Methods in Rarefied Gas Dynamics). Moscow, 1986. Pp. 81-85.

5. Vlasov V. I. Calculation of the aerodynamic characteristics of an infinite flat plate in a hypersonic rarefied gas flow (in Russian). Uchenye Zapiski TsAGI. 1971. V. No. 6. Pp. 116-120.

6. Vlasov V. I. Monte-Carlo calculation of heat flux between two parallel plates in a rarefied gas (in Russian). Uchenye Zapiski TsAGI. 1970. V. 1. No. 4. Pp. 46-51.

7. Vlasov V. I. Calculation of a rarefied gas flow about a plate at an angle of attack (in Russian). Uchenye Zapiski TsAGI. 1973. V. IV. No. 1. Pp. 17-24.

8. Vlasov V. I. Refinement of the Monte-Carlo method for calculating rarefied gas flows (in Russian). Doklady AN SSSR. 1966. V. 167. No. 5. Pp. 1016-1018.

9. Vlasov V. I. Calculation of a rarefied gas flow about a plate at an angle of attack (in Russian). Uchenye Zapiski TsAGI. 1975. V. VI. No. 2. . 48-56.

10. Abramovskaya M. G., Bass V. P., Pecherytsia L. L. On an algorithm of implementing the method of probe particles in rarefied gas dynamics (in Russian). Models and Methods of Aerodynamics: $3^{\text {rd }}$ International School Workshop: proceedings. Moscow: MTsNMO, 2003. Pp. 6-7.

11. Bass V. P., Pecherytsia L. L. Numerical simulation of a steady axisymmetric flow about a blunted cone in the transitional flow regime (in Russian). Visnyk Dnipropetrovskogo Universytetu. Mekhanika. 2005. V. 1. Issue 9. Pp. 57-66.

12. Bass V. P., Pecherytsia L. L. On a Monte-Carlo implementation algorithm for solving problems of rarefied gas dynamics (in Russian). Tekhnicheskaya Mekhanika. 2006. No. 1. Pp. 67-79.

13. Bass V. P., Pecherytsia L. L. Hypersonic rarefied gas flow about a heat-insulated cylinder (in Russian). Visnyk Dnipropetrovskogo Universytetu. Mekhanika. 2006. V. 1. Issue 10. Pp. 50-60.

14. Abramovskaya M. G., Bass . ., Petrushenko M. V. ,Pecherytsia L. L. Aerogasdynamics support of space projects (in Russian). Space Research in Ukraine 2004 - 2006. Kyiv: ISR NASU-NSAU, 2006. Pp. 78-86.

15. Abramovskaya M., Bass V., Petrushenko N., Percheritsa L. Aerogasdynamic aspects of space missions. Space Research in Ukraine 2004 - 2006. Kiev: ISR NASU-NSAU, 2006. Pp. 78-86.

16. Bass V. P., Pecherytsia L. L. Numerical simulation of a supersonic flow about two bodies one of which is in the wake of the other (in Russian). Model and Methods of Aerodynamics: $6^{\text {th }}$ International School Workshop: proceedings. Moscow: MTsNMO, 2006. Pp. 10-11. 
17. Abramovskaya M. G. , Bass V. P. , Petrushenko N. V. , Pecherytsia L. L., Smelaya T. G. Numerical simulation of mass transfer in the vicinity of spacecraft (in Russian). Model of Space: Scientific Information Edition. In 2 volumes. V. 2 / M. I. Panasyuk, L. S. Novikov (Eds.).-Moskow: KDU, 2007. Pp. 60-90.

18. Bass V. P., Pecherytsia L. L. Verification of methods and algorithms for the solution of problems of transition aerodynamics (in Russian). Tekhnicheskaya Mekhanika. 2007. No. 1. Pp. 49-61.

19. Bass V. P., Pecherytsia L. L. On the calculation of free molecular flow fields (in Russian). Tekhnicheskaya Mekhanika. 2008. No. 1. Pp. 73-82.

20. Bass V. P., Pecherytsia L. L. Calculation of 2D rarefied gas cross flows about a flat plate (in Russian). Tekhnicheskaya Mekhanika. 2008. No. 1. Pp. 83-92.

21. Bass V. P., Pecherytsia L. L. Numerical study of a supersonic rarefied gas flow about a plate-wedge configuration (in Russian). Tekhnicheskaya Mekhanika. 2009. No. 2. Pp. 62-69.

22. Bass V. P., Pecherytsia L. L. Behavior of the Magnus force in the case of a steady cross flow about a rotating cylinder in the Knudsen-transitional regime (in Russian). Tekhnicheskaya Mekhanika. 2009. No. 3. Pp. 6276.

23. Bass V. P., Pecherytsia L. L. Magnus force in the case of a steady flow about a rotating cylinder in the Knudsen-transitional regime (in Russian). Models and Methods of Aerodynamics: $9^{\text {th }}$ International School Workshop: proceedings. Moscow: MTsNMO, 2009. Pp. 15-16.

24. Bass V. P., Pecherytsia L. L. Numerical solution of 3D problems of rarefied gas dynamics (in Russian). Tekhnicheskaya Mekhanika. 2010. No. 2. Pp. 38-51.

25. Bass V. P., Pecherytsia L. L. Numerical simulation of 3D rarefied gas flows about bodies (in Russian). Models and Methods of Aerodynamics: $10^{\text {th }}$ International School Workshop: proceedings. Moscow: MTsNMO, 2010. Pp. 17-18.

26. Bass V. P., Pecherytsia L. L. Aerogasdynamic characteristics of the Sich-2 spacecraft at the stage of entry into the Earth's dense atmosphere (in Russian). Tekhnicheskaya Mekhanika. 2010. No. 3. Pp. 3-10.

27. Bass V. P., Pecherytsia L. L. Numerical simulation of steady jet efflux into a rarefied environment (in Russian). Models and Methods of Aerodynamics: $11^{\text {th }}$ International School Workshop: proceedings. Moscow: MTsNMO, 2011. Pp. 19-20.

28. Bass V. P., Pecherytsia L. L. Numerical simulation of steady efflux of a microthruster jet into a vacuum (in Russian) Tekhnicheskaya Mekhanika. 2011. No. 4. Pp. 82-87.

29. Pecherytsia L. L. Parallel algorithm of the method of probe particles for the solution of molecular gas dynamic problems (in Russian). Tekhnicheskaya Mekhanika. 2013. No. 1. Pp. 32-44.

30. Pecherytsia L. L. Features of a parallel algorithm of statistically independent tests of the method of probe particles (in Russian). Space Research in Ukraine 2014: abstracts. Kyiv: ISR NASU-NSAU, 2014. P. 122.

31. Pecherytsia L. L. Numerical study of parallelizing the method of probe particles in terms of statistically independent tests (in Russian). Tekhnicheskaya Mekhanika. 2015. No. 2. Pp. 100-109.

32. Clausing $P$. Uber die Stromung sehr Verdunnter Gase durch Rohren von beliebiger Lange. Ann. der Phys. 1932. V. 12. P. 961-989.

33. Beletsky V. V., Yanshin A. M. Effect of Aerodynamic Forces on Satellite Spin (in Russian). Kiev: Naukova Dumka, 1984. 188 pp.

34. Abramovskaya M. G., Bass V. P., Perminov V. D. et al. Altitude-2 Application Package. Description of Use (in Russian). Moscow: OFAP MAP, 1990. 175 pp.

35. Patent for Invention 6830222 USA, IPC 7 B 64 G 1/62. Balloon device for lowering space object orbit. K. T. Nock, A. D. McRonald, K. M. Aaron. 10/394477; filed March 21, 2003; published Dec. 14, 2004. 20 pp.

36. Patent for Invention No. 6550720 USA, IPC 7 B64G1/22. Fliter Aerobraking orbit transfer vehicle. DeBra D.B., P. Gloyer, Z. Wahl, D. Goldshtein. 09/925207; filed Aug. 9, 2001; published Apr. 22, 2003. 11 pp.

37. Alpatov A. P. Aerodynamic systems of space object deorbiting (in Russian). Tekhnicheskaya Mekhanika. 2015. No. 4. Pp. 126-138.

38. Patent for Invention 109194 Ukraine, IPC B 64 G 1/62. Aerodynamic system for the removal of space objects from near-Earth orbits (in Russian). Alpatov A. P., Paliy O. S., Skorik A. D., Baranov E. Yu., Osinovy G. G., Shevtsov V. I. Applicant and Patentee Institute of Technical Mechanics of the National Academy of Sciences of Ukraine and the State Space Agency of Ukraine. 201312759; filed Nov. 1, 2013; published July 27, 2015. Bul. No. 14. 12 pp.

39. USSR's State Standard 4401-81. Standard Atmosphere. Parameters (in Russian). Moscow: Standard Publishers, 1981. $179 \mathrm{pp}$.

40. Handbook for limiting orbital debris: NASA handbook 8719.14. hief B. O'Connor. Washington: DC, 2008. $174 \mathrm{pp}$.

41. Bass V. P. Molekular Gas Dynamics and its Applications in Rocket and Space Engineering (in Russian). Kiev: Naukova Dumka, 2008. 272 pp. 